\title{
Dietary fat and breast cancer risk revisited: a meta-analysis of the published literature
}

\author{
NF Boyd',', J Stone', KN Vogt', BS Connelly', LJ Martin' and S Minkin' \\ 'Division of Epidemiology and Statistics, Ontario Cancer Institute, 610 University Avenue, Toronto, Ontario, Canada M5G IK9
}

\begin{abstract}
Animal experiments and human ecological studies suggest that dietary fat intake is associated with a risk of breast cancer, but individual-based studies have given contradictory results. We have carried out a meta-analysis of this association to include all papers published up to July 2003. Case-control and cohort studies that examined the association of dietary fat, or fat-containing foods, with risk of breast cancer were identified. A total of 45 risk estimates for total fat intake were obtained. Descriptive data from each study were extracted with an estimate of relative risk and its associated $95 \%$ confidence interval $(\mathrm{Cl})$, and were analysed using the random effects model of DerSimonian and Laird. The summary relative risk, comparing the highest and lowest levels of intake of total fat, was I.I 3 (95\% Cl: I.03-1.25). Cohort studies $(\mathrm{N}=14)$ had a summary relative risk of I. I I (95\% Cl: $0.99-1.25)$ and case-control studies $(\mathrm{N}=3 \mathrm{I})$ had a relative risk of $\mathrm{I} .14(95 \% \mathrm{Cl} 0.99-1.32)$. Significant summary relative risks were also found for saturated fat (RR, I.I 9 ; 95\% Cl: 1.06-1.35) and meat intake (RR, I.17; 95\% Cl 1.06-1.29). Combined estimates of risk for total and saturated fat intake, and for meat intake, all indicate an association between higher intakes and an increased risk of breast cancer. Case-control and cohort studies gave similar results.
\end{abstract}

British Journal of Cancer (2003) 89, 1672-1685. doi:I0.1038/sj.bjc.66013।4 www.bjcancer.com

(c) 2003 Cancer Research UK

Keywords: diet; fat; breast cancer risk; meta-analysis

Breast cancer is the leading cause of cancer death, and the most frequently diagnosed cancer in women worldwide (Lacey et al, 2002). Large differences in rates of the disease exist between countries, with higher rates in North America and Western Europe, and lower rates in Asia and South America (Lacey et al, 2002). These differences are likely to be due to environmental rather than genetic factors. The rates of breast cancer change in migrants from low- to high-risk countries, who eventually acquire the rates of their adopted country (Ziegler et al, 1993; Pike et al, 2002). Menstrual and reproductive risk factors for breast cancer do not appear to account for these differences in rates $(\mathrm{Wu}$ et al, 1996).

The differences in dietary practices between countries are well established, and could contribute to the differences in breast cancer risk. Support for an influence of dietary fat on breast cancer rates comes from its effect on mammary carcinogenesis in animals, and human ecological data.

Two major meta-analyses, combining results from over 140 studies examining the relationship between dietary fat and breast cancer risk in rats and mice, show dietary fat to be a promoter of mammary carcinogenesis (Fay et al, 1997). This effect is independent of the effects of caloric intake (Freedman et al, 1990). Human ecological studies show a strong correlation $(0.7$ or more) between dietary fat intake, estimated from national food balance data, and incidence and mortality of breast cancer worldwide. (Prentice and Sheppard, 1990).

*Correspondence: Dr NF Boyd; E-mail: boyd@uhnres.utoronto.ca Received II June 2003; revised 13 August 2003; accepted 13 August 2003
However, case-control and cohort studies that have examined the relationship between dietary fat and breast cancer risk in humans have given inconclusive results. In 1993, we conducted a meta-analysis of the 23 studies then published that gave risk estimates for the total dietary fat, type of fat or for fat-containing foods (Boyd et al, 1993). The number of published primary research papers on this issue has since then more than doubled. The present analysis updates and expands our earlier metaanalysis to include all studies on this relationship published since 1993.

\section{METHODS}

\section{Assembly of literature}

Case-control and cohort studies for inclusion in the analysis were identified by searching the MEDLINE and PUBMED databases for literature on the intake of fat, fat subtypes and fat-containing foods, and breast cancer risk over the period from January 1966 to July 2003. Reference lists of review articles and primary studies were also searched for additional relevant literature.

A total of 46 risk estimates for total fat intake were obtained from the 45 independent studies included in the meta-analysis (see Table 1 for references). Risk estimates for types of fat were also extracted from the 33 studies that provided them.

Studies were also identified that contained information regarding food groups and breast cancer risk. The three most common foods for which risk estimates were given in these studies were determined (meat, milk and cheese) and used in the present metaanalysis. Two studies, which defined food groups in a manner that 
Table I Selected characteristics of (A) case-control studies: total fat and (B) cohort studies: total fat

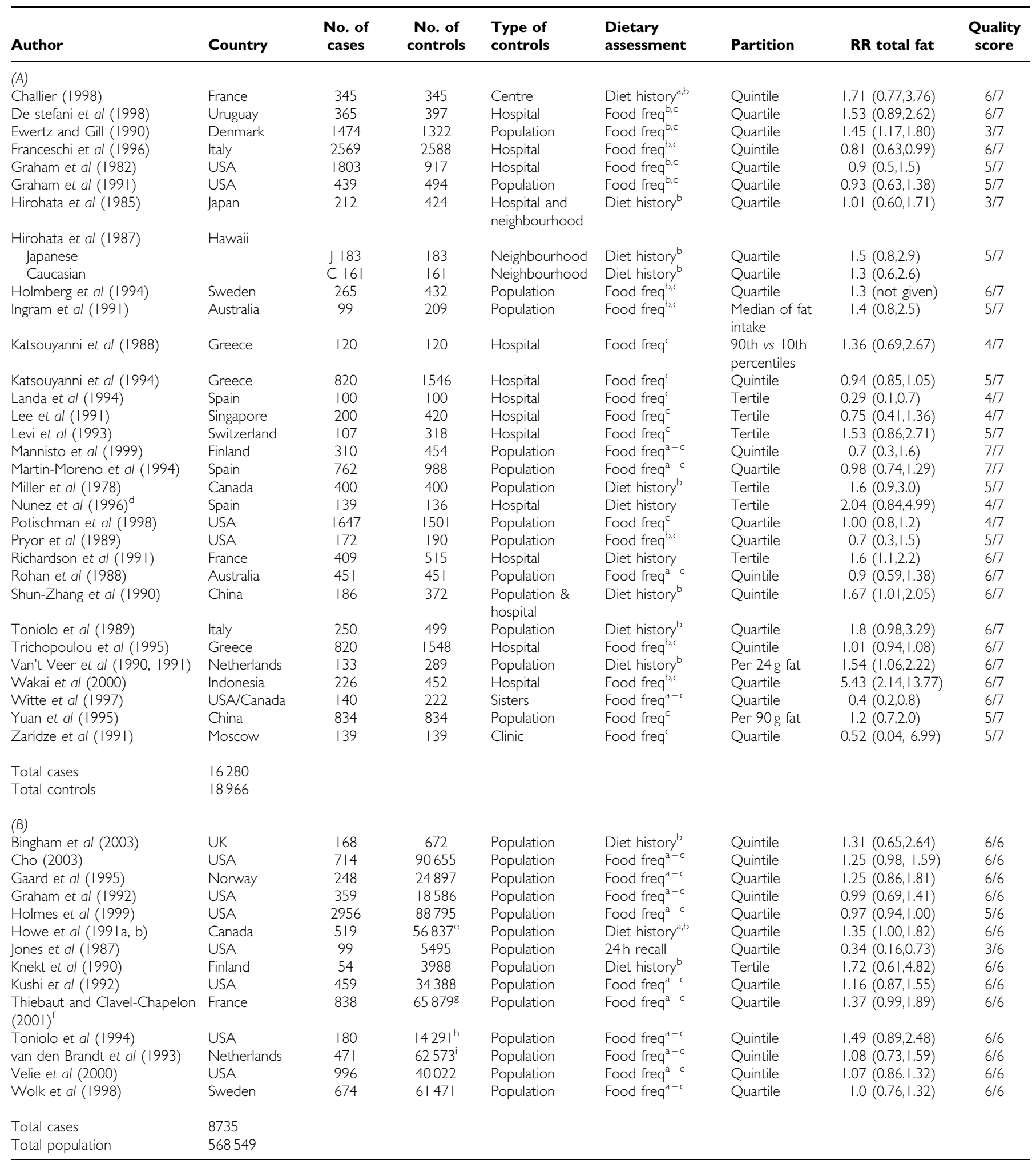

a Self-administered. ${ }^{b}$ Diet assessment method validated. ${ }^{\mathrm{c}}$ Food Frequency Questionnaire. ${ }^{\mathrm{d}}$ Article translated from Spanish. ${ }^{\mathrm{e}}$ No. of controls in calculation of RR $=1 / 82 .{ }^{\mathrm{f}}$ Article translated from French. ${ }^{8} \mathrm{No}$. of controls in calculation of $R R=62211$. hNo. of controls in calculation of $R R=829$. 'No. of controls in calculation of $R R=1598$.

could not be adapted to this analysis, were excluded (Katsouyanni et al, 1986; Lubin et al, 1986). Risk estimates pertaining to the intake of these foods were obtained from a total of 36 papers (see Table 2 for references), 16 of which also contained relative risk estimates associated with total fat intake. Nested case-control studies were treated as cohort studies for these analyses. If study results were presented in more than one article, the most recent analysis was used. 


\section{Dietary fat and breast cancer}

NF Boyd et al

Table 2 Selected characteristics of (A) case-control studies: food and (B) cohort studies: food

\begin{tabular}{|c|c|c|c|c|c|c|c|c|c|c|}
\hline Author & Country & $\begin{array}{l}\text { No. of } \\
\text { cases }\end{array}$ & $\begin{array}{l}\text { No. of } \\
\text { controls }\end{array}$ & $\begin{array}{l}\text { Type of } \\
\text { controls }\end{array}$ & $\begin{array}{l}\text { Dietary } \\
\text { assessment }\end{array}$ & Food & $\begin{array}{c}\text { No of } \\
\text { categories }^{a}\end{array}$ & $\mathbf{R R}^{\mathbf{i}}$ & Cl & $\begin{array}{l}\text { Quality } \\
\text { score }\end{array}$ \\
\hline \multicolumn{11}{|l|}{ (A) } \\
\hline $\begin{array}{l}\text { Ambrosone et al } \\
\text { (1998) }\end{array}$ & USA & 740 & 810 & Population & Food freq ${ }^{b}$ & Meat $^{c}$ & 4 & 0.92 & $(0.25,3.32)$ & $5 / 7$ \\
\hline $\begin{array}{l}\text { De stefani et al } \\
\text { (1997) }\end{array}$ & Uruguay & 352 & 382 & Hospital & Food freq ${ }^{b, d}$ & Meat & 4 & 2.26 & $(1.24,4.12)$ & $5 / 7$ \\
\hline \multirow{2}{*}{$\begin{array}{l}\text { Ewertz and Gill } \\
\text { (1990) }\end{array}$} & Denmark & 1474 & 1322 & Population & Food freq $q^{b, d}$ & Meat & 6 & 0.94 & $(0.63,1.40)$ & $3 / 7$ \\
\hline & & & & & & Milk & 5 & 1.45 & $(1.02,2.07)$ & $5 / 7$ \\
\hline \multirow{3}{*}{$\begin{array}{l}\text { Franceschi et al } \\
\text { (1995) }\end{array}$} & Italy & 2569 & 2588 & Hospital & Food freq ${ }^{b, d}$ & Meat & 4 & 0.99 & $(0.69,1.41)$ & $6 / 7$ \\
\hline & & & & & & Milk & 5 & 0.81 & $(0.67,0.98)$ & \\
\hline & & & & & & Cheese & 5 & 0.98 & $(0.81,1.18)$ & \\
\hline Hirohata et al (1987) & USA & 183 & 183 & Population & Diet history $^{d}$ & Meat & 4 & 1.5 & $(0.7,3.1)$ & $5 / 7$ \\
\hline \multirow[t]{2}{*}{ Hislop et al (1986) } & Canada & 846 & 862 & Population & Food freq,e & Meat & 3 & 1.16 & $(0.90,1.48)$ & $3 / 7$ \\
\hline & & & & & & Milk & 3 & 1.55 & $(1.18,2.05)$ & \\
\hline $\begin{array}{l}\text { Holmberg et al } \\
\text { (1994) }\end{array}$ & Sweden & 265 & 432 & Population & Food freq ${ }^{\mathrm{b}, \mathrm{d}}$ & Meat & 8 & 0.8 & $(0.5,1.2)$ & $6 / 7$ \\
\hline \multirow[t]{2}{*}{ Ingram et al (1991) } & Australia & 99 & 209 & Population & Food freq ${ }^{b}$ & Meat & 2 & 1.6 & $(0.9,2.8)$ & $3 / 7$ \\
\hline & & & & & & Milk & 2 & 0.9 & $(0.5,1.6)$ & \\
\hline Kato et al (1992) & Japan & 908 & 908 & Hospital & Unspecified & Meat & 3 & 0.75 & $(0.60,0.94)$ & $2 / 7$ \\
\hline Landa et al (1994) & Spain & 100 & 100 & Hospital & Food freq $^{b}$ & Meat & 3 & 1.21 & $(0.31,4.66)$ & $4 / 7$ \\
\hline $\begin{array}{l}\text { La Vecchia et al } \\
\text { (1987) }\end{array}$ & Italy & 1108 & $|28|$ & Hospital & Food freq & Meat & 3 & 1.39 & $(1.12,1.71)$ & $4 / 7$ \\
\hline \multirow[t]{2}{*}{ Le et al (1986) } & France & 1010 & 1950 & Hospital & Food freq $^{b}$ & Milk & 3 & 1.8 & $(1.3,2.4)$ & $5 / 7$ \\
\hline & & & & & & Cheese & 3 & 1.5 & $(1.0,2.3)$ & \\
\hline Lee et al (1991) & Singapore & 200 & 420 & Hospital & Food freq ${ }^{b}$ & Meat & 3 & 1.4 & $(0.77,2.53)$ & $4 / 7$ \\
\hline \multirow[t]{3}{*}{ Levi et al (1993) } & Switzerland & 107 & 318 & Hospital & Food freq ${ }^{b}$ & Meat $^{c}$ & 3 & 1.45 & $(0.56,3.72)$ & $5 / 7$ \\
\hline & & & & & & Milk & 3 & 1.15 & $(0.68,1.96)$ & \\
\hline & & & & & & Cheese & 3 & 2.99 & $(1.7,5.25)$ & \\
\hline \multirow[t]{3}{*}{ Lubin et al (|98|) } & Canada & 577 & 826 & Population & Food freq ${ }^{b}$ & Meat & 3 & 1.42 & $(1.0,2.0)$ & $4 / 7$ \\
\hline & & & & & & Milk & 4 & 0.77 & $(0.5,1.3)$ & \\
\hline & & & & & & Cheese & 3 & I.I | & $(0.9,1.4)$ & \\
\hline \multirow[t]{3}{*}{ Mannisto et al (1999) } & Finland & 310 & 454 & Population & Food freq ${ }^{\mathrm{b}, \mathrm{d}, \mathrm{e}}$ & Meat & 5 & 0.66 & $(0.12,3.72)$ & $7 / 7$ \\
\hline & & & & & & Milk & 4 & 1.7 & $(0.8,3.66)$ & \\
\hline & & & & & & Cheese & 4 & 0.75 & $(0.3,1.7)$ & \\
\hline Matos et al (|99|) & Argentina & 196 & 205 & Neighbourhood & Food freq ${ }^{b}$ & Meat & 3 & 1.4 & $(0.7,2.9)$ & $4 / 7$ \\
\hline $\begin{array}{l}\text { Potischman et al } \\
\text { (1998) }\end{array}$ & USA & 1647 & $150 \mid$ & Population & Food freq & Meat & 4 & 1.18 & $(1.0,1.5)$ & $4 / 7$ \\
\hline \multirow{2}{*}{$\begin{array}{l}\text { Richardson et al } \\
(1991)\end{array}$} & France & 409 & 515 & Hospital & Diet history ${ }^{b}$ & Meat & 3 & I & $(0.7,1.4)$ & $6 / 7$ \\
\hline & & & & & & Cheese & 3 & 1.4 & $(1.0,1.9)$ & \\
\hline \multirow[t]{2}{*}{ Talamini et al (1984) } & Italy & 368 & 373 & Hospital & Food freq & Meat & 3 & 1.3 & $(0.7,2.2)$ & $4 / 7$ \\
\hline & & & & & & Milk & 3 & 3.2 & $(1.85,5.8)$ & \\
\hline \multirow[t]{3}{*}{ Toniolo et al (1989) } & Italy & 250 & 499 & Population & Diet history $^{d}$ & Meat $^{c}$ & 4 & 1.15 & $(0.82,1.62)$ & $6 / 7$ \\
\hline & & & & & & Milk & 4 & 1.73 & $(1.16,2.6)$ & \\
\hline & & & & & & Cheese & 4 & 2.6 & $(1.7,4.0)$ & \\
\hline \multirow{2}{*}{$\begin{array}{l}\text { Trichopoulou et al } \\
\text { (1995) }\end{array}$} & Greece & 820 & 1548 & Hospital visitors & Food freq ${ }^{b, d}$ & Meat & 5 & 1.07 & $(0.99,1.15)$ & $6 / 7$ \\
\hline & & & & & & Milk & 5 & 1.0 & $(0.93,1.08)$ & \\
\hline \multirow{2}{*}{$\begin{array}{l}\text { Van't Veer et al } \\
(1989)\end{array}$} & Netherlands & 133 & 289 & Population & Diet history & Milk & Per $225 \mathrm{~g}$ & 0.81 & $(0.59,1.12)$ & $4 / 7$ \\
\hline & & & & & & Cheese & Per $60 \mathrm{~g}$ & 0.56 & $(0.33,0.95)$ & \\
\hline \multirow{2}{*}{$\begin{array}{l}\text { Witte et al (1997) } \\
\text { Wang et al (2000) }\end{array}$} & USA/Canada & 140 & 222 & Population & Food freq ${ }^{\mathrm{b}, \mathrm{d}, \mathrm{e}}$ & Meat & 4 & 0.6 & $(0.3,1.3)$ & $6 / 7$ \\
\hline & China & 2063 & 2063 & Neighbourhood & Food freq ${ }^{b}$ & Milk & Per $500 \mathrm{~g}$ & 1.49 & Not given & \\
\hline Total cases & 16734 & & & & & & & & & \\
\hline Total controls & 20038 & & & & & & & & & \\
\hline \multicolumn{11}{|l|}{ (B) } \\
\hline Cho (2003) & USA & 714 & 90655 & Population & Food freq ${ }^{b, e, d}$ & Meat $^{c}$ & 5 & 1.11 & $(0.92,1.35)$ & $6 / 6$ \\
\hline \multirow{2}{*}{ Gaard et al (1995) } & Norway & 248 & 25897 & Population & Food freq ${ }^{b, e, d}$ & Meat & 4 & 2.28 & $(1.29,4.03)$ & $6 / 6$ \\
\hline & & & & & & Milk & 4 & 1.71 & $(0.86,3.38)$ & \\
\hline
\end{tabular}


Table 2 (Continued)

\begin{tabular}{|c|c|c|c|c|c|c|c|c|c|c|}
\hline Author & Country & $\begin{array}{l}\text { No. of } \\
\text { cases }\end{array}$ & $\begin{array}{l}\text { No. of } \\
\text { controls }\end{array}$ & $\begin{array}{l}\text { Type of } \\
\text { controls }\end{array}$ & $\begin{array}{l}\text { Dietary } \\
\text { assessment }\end{array}$ & Food & $\begin{array}{c}\text { No of } \\
\text { categories }^{a}\end{array}$ & $\mathbf{R R}^{\mathbf{i}}$ & Cl & $\begin{array}{l}\text { Quality } \\
\text { score }\end{array}$ \\
\hline Gertig et al (1999) & USA & 466 & 466 & Population & Food freq ${ }^{b, d, e}$ & Meat $^{c}$ & 3 & 1.06 & $(0.48,2.33)$ & $6 / 7$ \\
\hline Hirayama (1978) & Japan & 139 & | 42857 & Population & $\begin{array}{l}\text { National nutrition } \\
\text { survey }\end{array}$ & Meat & 2 & 1.7 & $(0.8,3.8)$ & $3 / 6$ \\
\hline Hjartaker et al (200I) & Norway & 317 & 48844 & Population & Food freq ${ }^{b, d, e}$ & Milk & 3 & 0.51 & $(0.27,0.96)$ & $5 / 6$ \\
\hline Kinlen (1982) & Britain & 62 & 2813 & Population & Unspecified & Meat & 2 & 1.2 & $(0.8,1.6)$ & $2 / 6$ \\
\hline \multirow[t]{2}{*}{ Knekt et al (1996) } & Finland & 88 & 4697 & Population & Food freq ${ }^{b, d}$ & Milk & 3 & 0.42 & $(0.24,0.74)$ & $4 / 6$ \\
\hline & & & & & & Cheese & 3 & 1.25 & $(0.75,2.08)$ & \\
\hline \multirow[t]{3}{*}{ Mills et al (1989) } & USA & 215 & 20341 & Population & Food freq & Meat $^{c}$ & 3 & 1.11 & $(0.47,2.66)$ & $4 / 6$ \\
\hline & & & & & & Milk & 3 & 0.94 & $(0.66,1.33)$ & \\
\hline & & & & & & Cheese & 3 & 1.43 & $(0.99,2.06)$ & \\
\hline $\begin{array}{l}\text { Thiebaut and Clavel- } \\
\text { Chapelon }(2001)^{g}\end{array}$ & France & 838 & 65879 & Population & Food freq ${ }^{b, d, e}$ & Cheese & 4 & 0.92 & $(0.74,1.13)$ & $6 / 6$ \\
\hline Toniolo et al (1994) & USA & 180 & 829 & Population & Food freq ${ }^{b, d, e}$ & Meat & 5 & 1.44 & $(0.68,3.04)$ & $6 / 6$ \\
\hline $\begin{array}{l}\text { van den Brandt et al } \\
\text { (1993) }\end{array}$ & Netherlands & 437 & $62573^{h}$ & Population & Food freq ${ }^{b, d, e}$ & Meat & Not given & 1.23 & $(0.63,2.37)$ & $6 / 6$ \\
\hline Vatten et al (1990) & Norway & 152 & 14500 & Population & Food freq ${ }^{b, d}$ & Meat & 3 & 1.8 & $(1.1,3.1)$ & $4 / 6$ \\
\hline Total cases & 3783 & & & & & & & & & \\
\hline Total controls & 476200 & & & & & & & & & \\
\hline
\end{tabular}

${ }^{a}$ Food Frequency Questionnaire. ${ }^{b}$ Self-administered. ${ }^{\mathrm{c}}$ Diet assessment method validated. ${ }^{\mathrm{d}} \mathrm{No}$. of categories refers to the number of categories of frequency of consumption into which the food intakes were partitioned. The RR is the highest vs lowest level of consumption. ${ }^{\mathrm{e}}$ Article translated from Chinese. ${ }^{\mathrm{f}}$ Article translated from French. ${ }^{\mathrm{g}} \mathrm{No}$. of controls in calculation of $R R=1598$. hMeasurement of food intake assessed for validity. 'RR presented for various types of meat combined to reflect total meat consumption.

\section{Extraction and classification of data}

Descriptive data regarding the number and type of subjects, estimates of mean daily dietary fat intake, method of dietary assessment and the partitioning of intakes for the calculation of relative risks were extracted from each article along with an estimate of relative risk and its associated 95\% confidence (CI) interval. In these studies, the intake of fat or fat-containing foods was usually partitioned into tertiles, quartiles or quintiles. The relative risk of breast cancer comparing the highest with the lowest category of intake was extracted from each study. Relative risks and CIs were calculated for three studies (Graham et al, 1982, 1991; Yuan et al, 1995) and confidence intervals were calculated for five studies (Hirayama, 1978; Kinlen, 1982; Levi et al, 1993; Landa et al, 1994; Toniolo et al, 1994) by cell frequencies shown in the data or standard error values (Fleiss, 1981), and are thus unadjusted for other variables.

If the risk of breast cancer associated with the dietary variables was expressed in more than one way, the estimate extracted from the study was the one that reflected the greatest degree of controlling for confounders (i.e. risk factors and/or energy). When both hospital and population controls were used for comparison separately, the results for population controls were chosen for analysis. As few studies provided complete data for pre- and postmenopausal women separately, we chose the relative risk for the whole group if available. In some reports unadjusted relative risks were given, accompanied by an explicit statement that the estimate was unchanged by adjustment for energy or other risk factors. In these cases, the relative risk given was regarded as having been adjusted.

In some instances, more than one estimate of risk were combined in order to increase the comparability of the studies. For example, in a number of studies of fat-containing foods, separate estimates of risk for red meat, poultry or pork consumption were reported. These separate risk estimates were combined into a total meat group by averaging the log of the risk estimates. CIs were calculated for the average relative risk using the variances of each separate risk estimate. In two studies, relative risk estimates were given for pre- and postmenopausal women separately (Pryor et al, 1989; Ambrosone et al, 1998) and in one study, risk estimates were given for pre- and postmarriage separately (Wakai et al, 2000). In each of these cases, the estimates were combined into one to represent all women in the manner described above. Similarly, in the cohort study reported by Hirayama (1978), relative risks given for meat intake divided by age category were combined to produce one risk estimate for the population.

\section{Methodological standards}

A quality score was calculated for each study included in the metaanalysis. Four investigators (NFB, LJM, KNV and BSC) independently scored the studies based on predetermined methodological standards and any differences were resolved by discussion. The criteria included the provision of details on how the population had been assembled, whether histological confirmation of breast cancer had been obtained, the methods used to control for observer bias, a description of the method of measurement of nutrient and/or food intake, including data on validation and reproducibility and whether or not adjustment of risk estimates for potential confounding factors such as energy intake and traditional risk factors for breast cancer had been performed. Quality scores were not used to weigh the individual estimates of risk, but were used to divide the studies into groups for a stratified analysis based on quality score.

\section{Statistical methods and analysis}

Studies were classified as case-control or cohort and statistical analyses were performed for each study design separately as well as for all studies combined. Analyses were also performed on subgroups of studies based on quality score, geographical area, type of control population and other study characteristics.

Statistical analyses were performed using SAS (SAS Institute, Inc., Cary, NC, USA) software and graphical displays of the results produced using S-PLUS (Insightful, Inc., Seattle, WA, USA) software. The data required by SAS for each study included the natural $\log$ of the adjusted odds ratios, and its 95\% CI. From these, 
the program calculated the summary risk estimate and the associated standard error, which was used to determine the $95 \%$ CI.

Owing to diversity in the location, design and analysis of the various studies, we were aware that the true effects being estimated were likely to vary among studies. There were two sources of variability that had to be addressed: the usual sampling variation in the estimates and variation in the underlying parameter. To account for both sources of variation in this meta-analysis, we used the method of DerSimonian and Laird (1986), employing the SAS MIXED procedure in which the magnitude of the heterogeneity is estimated, and accounted for by assigning a greater variability to the estimate of the overall effect. Thus, we did not assume that the studies represented the same effect. Rather, the effects came from some statistical distribution of effects. The random effects model does not rely on homogeneity; on the contrary, it assumes heterogeneity. We also employed additional subgroup and regression analyses to try to account for the observed differences between studies, and to examine the potential influence of study design and execution, study population, geographical location, adjustment variables, partitioning cut points and methods of analysis.

\section{RESULTS}

\section{Characteristics of studies reported}

A total of 45 published studies, containing 46 estimates of risk, examined the role of dietary fat in relation to breast cancer risk by an analysis of nutrient intake. Of these, 31 were case control and 14 were cohort in design, and they contained a total of 25015 cases of breast cancer and over 580000 control or comparison subjects. Table 1 summarises selected characteristics of the published studies that examined the role of dietary fat in relation to breast cancer risk through an analysis of nutrient intake. In all, 22 studies were carried out in European countries (including Russia), five in Asian countries, and 15 in North America. In addition, two studies were conducted in Australia and one in Uruguay.

The studies included in Table 1 had varied methods of execution and analysis. A total of 27 studies used population-based comparison or controls, 12 selected comparison subjects from hospital or clinics, two studies selected comparison subjects from both these sources and four selected controls from other defined populations (i.e. sisters, neighbourhood, or centre). In total, 32 studies obtained dietary data using food frequency questionnaires,

A

Case-control:

Total fat

Challier (1998)

DeStefani (1998)

Ewertz (1990)

Franceschi (1996)

Graham (1982)

Graham (1991)

Hirohata (1985)

Hirohata (1987) (Japanese)

Ingram (1991)

Katsouyanni (1988)

Katsouyanni (1994)

Landa (1994)

Lee (1991)

Levi (1993)

Mannisto (1999)

Martin-Moreno (1994)

Miller (1978)

Núñez (1996)

Potischman(1998)

Pryor (1989)

Richardson (1991)

Rohan (1988)

Shun-Zhang (1990)

Toniolo (1989)

Trichopoulou (1995)

van't Veer $(1990,1991)$

Wakai (2000)

Witte (1997)

Yuan (1995)

Zaridze (1991)

Case-control summary

Cohort:

Bingham (2003)

Cho (2003)

Gaard (1995)

Graham (1992)

Holmes (1999)

Jones (1987)

Jones (1987)

Knekt (1990)

Kushi (1992)

Thiébaut (2001)

Toniolo (1994)

van den Brandt (1993)

Velie (2000)

Wolk (1998)

Cohort summary

All studies summary
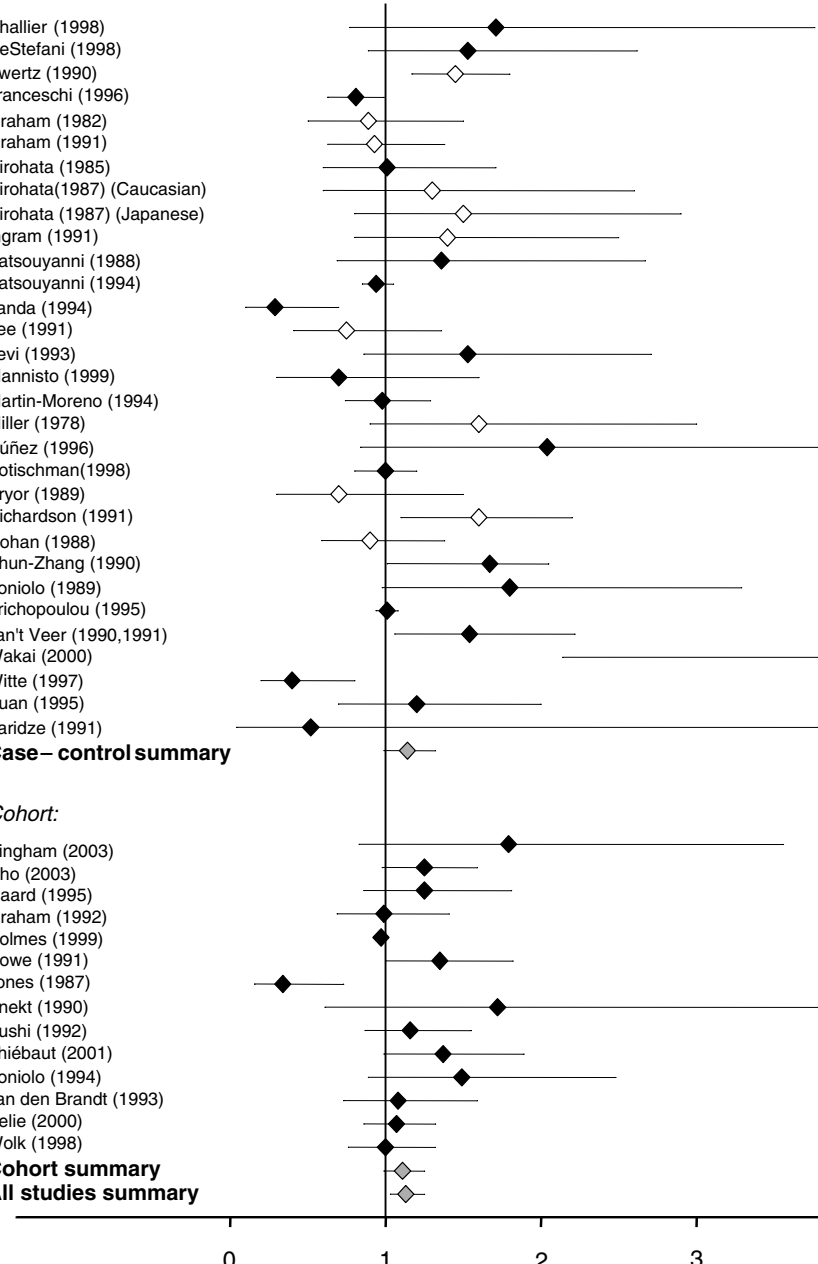

0
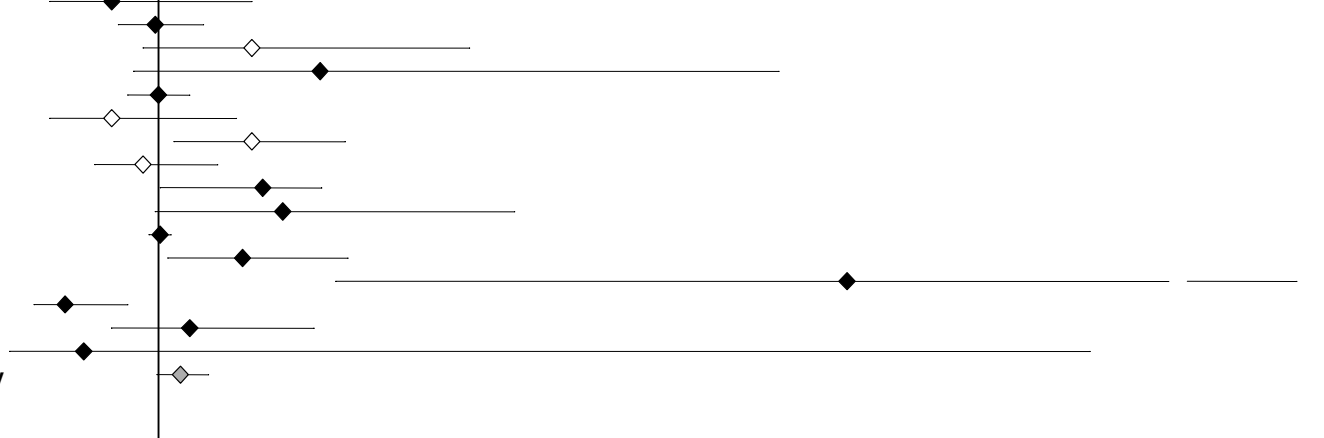
B

Case-control:
Saturated fat

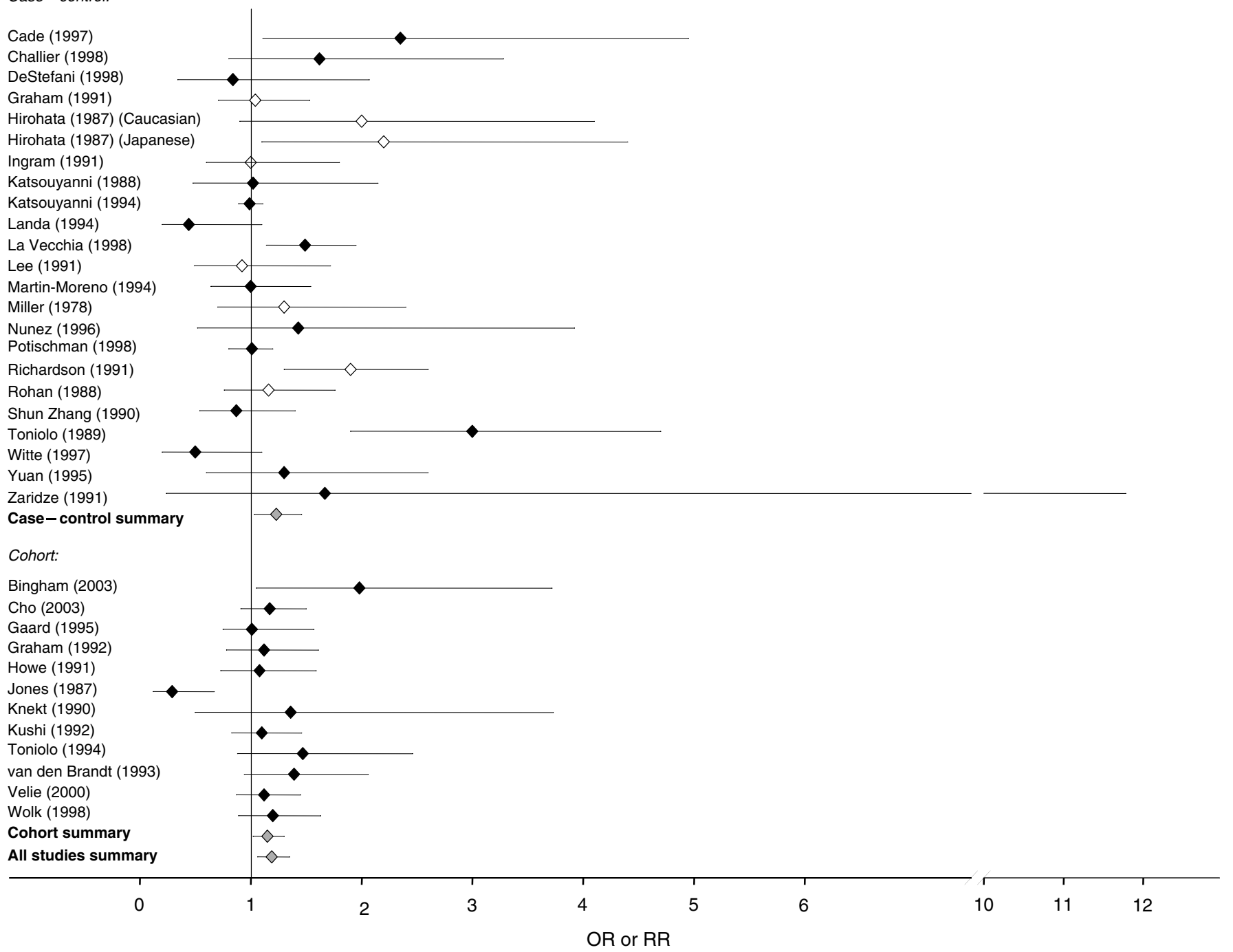

Figure I (Continued)

12 with diet histories, one with a 24-h diet recall and one with food records and food frequency questionnaire. Food frequency questionnaires were sometimes administered by interview, and sometimes self-administered, and differed substantially in the number of food items included (data not shown in the table).

All the studies included in Table 1 analysed the relationship between breast cancer risk and nutrient intake by partitioning intake, 13 by quintiles, 21 by quartiles, seven by tertiles and one at the median. One study used deciles of intake and two used specific increments in fat intake. A total of 26 studies met at least six of the methodological standards that were applied, 16 met four or five standards and three met fewer than four standards.

\section{Estimates of risk for nutrient consumption}

Figure 1 shows the estimates of the risk of breast cancer generated by these studies for total fat, as well as saturated, monounsaturated and polyunsaturated fat, and indicates where risk estimates have been adjusted for energy intake and for established breast cancer risk factors. For total fat, the summary relative risk for all 46 estimates was 1.13 (95\% CI: $1.03-1.25)$. Cohort studies had a summary relative risk of 1.11 (95\% CI: $0.99-1.25)$ and case-control studies had a relative risk of 1.14 (95\% CI: $0.99-1.32)$. Summary relative risks for both cohort and case-control studies that adjusted for energy intake and traditional risk factors for breast cancer were 1.13 (95\% CI: $1.04-1.23)$ and 1.22 (95\% CI: 0.91-1.63), respectively. The summary relative risks for saturated fat were greater than unity for all studies combined (RR, 1.19; 95\% CI: 1.06-1.35), case-control studies alone (RR, 1.23; 95\% CI: 1.03-1.46) and cohort studies alone (RR, 1.15; 95\% CI: $1.02-1.30)$. The summary relative risk for monounsaturated fat was 1.11 (95\% CI: $0.96-1.28)$ for all studies, 1.12 for case - control studies alone (95\% CI: $0.94-1.32$ ) and 1.10 for cohort studies alone (95\% CI: $0.83-1.44)$. The summary relative risks for polyunsaturated fats were below unity for all studies and case-control studies alone (all studies, $0.94 ; 95 \%$ CI: $0.80-1.10$, case control, 0.50 ; $95 \%$ CI: $0.39-0.63$ ), but above unity for cohort studies alone (1.11; 95\% CI: $1.00-1.22)$.

\section{Replication of published results of a combined analysis of cohort studies}

To determine whether the methods used in the present paper could replicate those based upon an analysis using the data from individual studies, we applied our methods to a group of studies 


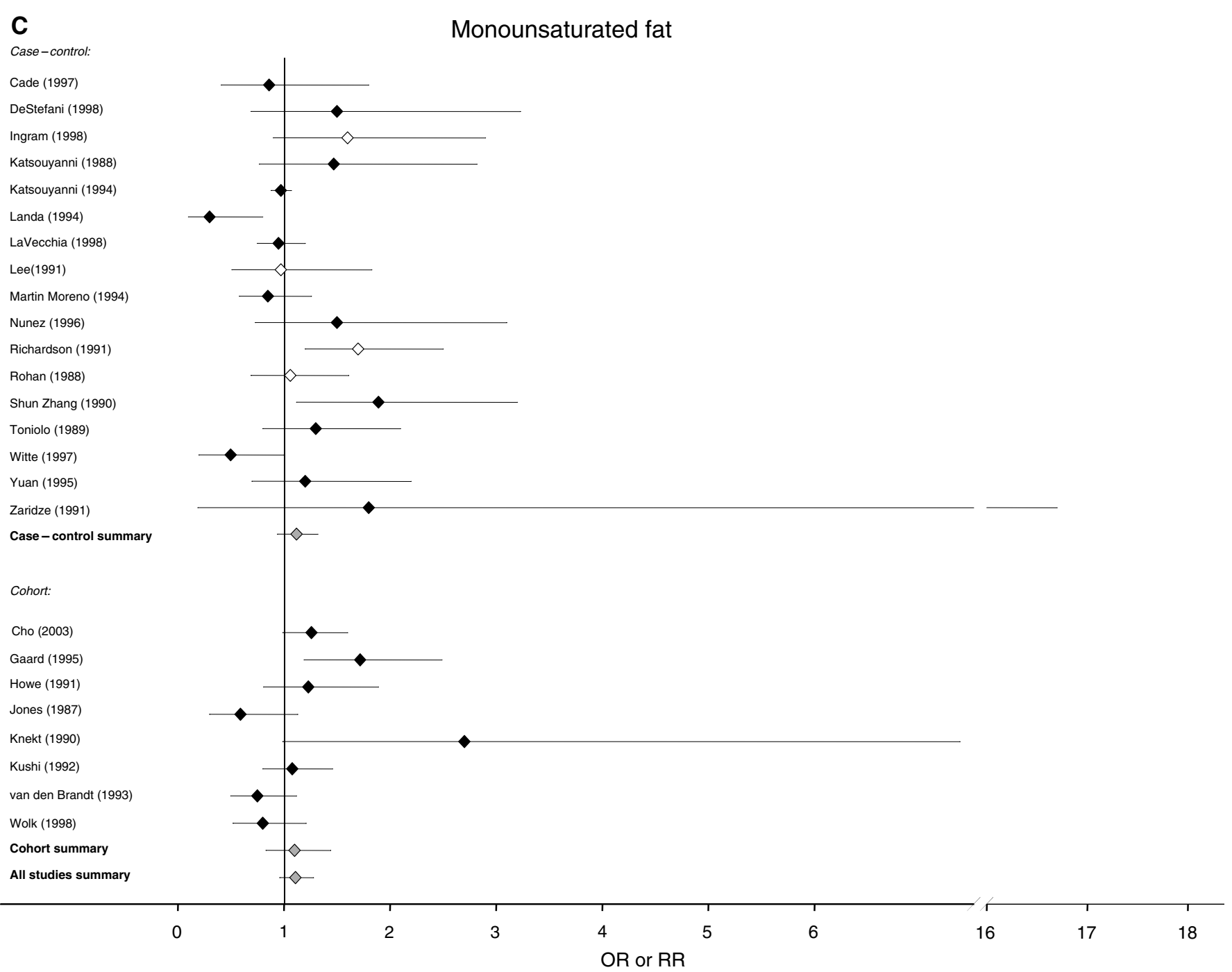

Figure I (Continued)

that were the subject of a previously published pooled analysis of seven cohort studies by Hunter et al (1996). For our analysis, we extracted risk estimates and $95 \%$ CIs from the original papers and calculated the summary risk estimates as described above. Estimates for total fat were available for five of the seven studies analysed by Hunter et al (Howe et al, 1991a; Graham et al, 1992; Kushi et al, 1992; Willett et al, 1992; van den Brandt et al, 1993). Comparing our results with those of Hunter's analysis, the summary relative risks for total fat were, respectively, 1.06 (95\% CI: $0.92-1.23)$ and 1.05 (95\% CI: 0.94-1.16), for saturated fat 1.05 (95\% CI: $0.90-1.23)$ and 1.07 (95\% CI: $0.95-1.20$ ), for monounsaturated fat 0.96 (95\% CI: $0.83-1.10)$ and 1.01 (95\% CI: $0.88-1.16)$ and for polyunsaturated fat 1.14 (95\% CI: $0.98-1.34$ ) and 1.07 (95\% CI: 0.97-1.17), respectively. Our calculations thus produced risk estimates and CIs very similar to those reported from the pooled analysis.

\section{Characteristics of studies reporting analysis according to foods}

The 37 studies that examined food consumption in relation to breast cancer risk, 25 case-control and 12 cohort in design, included a total of 20571 cases and over 490000 control or comparison subjects. The 37 studies contained 31 estimates of risk for meat, 16 for milk and 11 for cheese. There is some overlap, as 16 studies reported risk in relation to consumption of both nutrients and foods, and are therefore included in both Figures 1 and 2 .

Table 2 summarises selected characteristics of the published studies that examined the role of diet in relation to breast cancer risk by an analysis of food intake. A total of 20 studies were carried out in European countries, 10 in North America, four in Asian countries and one in each of Argentina, Australia and Uruguay. A total of 24 studies used population-based comparison or controls, 10 selected comparisons from hospitals and three selected comparisons from other populations (i.e. neighbourhood and hospital visitors). All but seven studies obtained dietary data using a food frequency questionnaire, of which two used unspecified methods.

All the studies included in Table 2 analysed the relationship between breast cancer risk and food intake by partitioning intake. Differences in the methods of partitioning existed not only between studies but also within studies analysing intake of different foods. In all, 13 studies met at least six of the methodological standards that were applied, 18 met four or five, and six met fewer than four standards.

\section{Estimates of risk for food consumption}

Figure 2 shows the distribution of the estimates of risk of breast cancer and the $95 \%$ CIs generated by the studies for intake of meat, 
D

\section{Polyunsaturated fat}

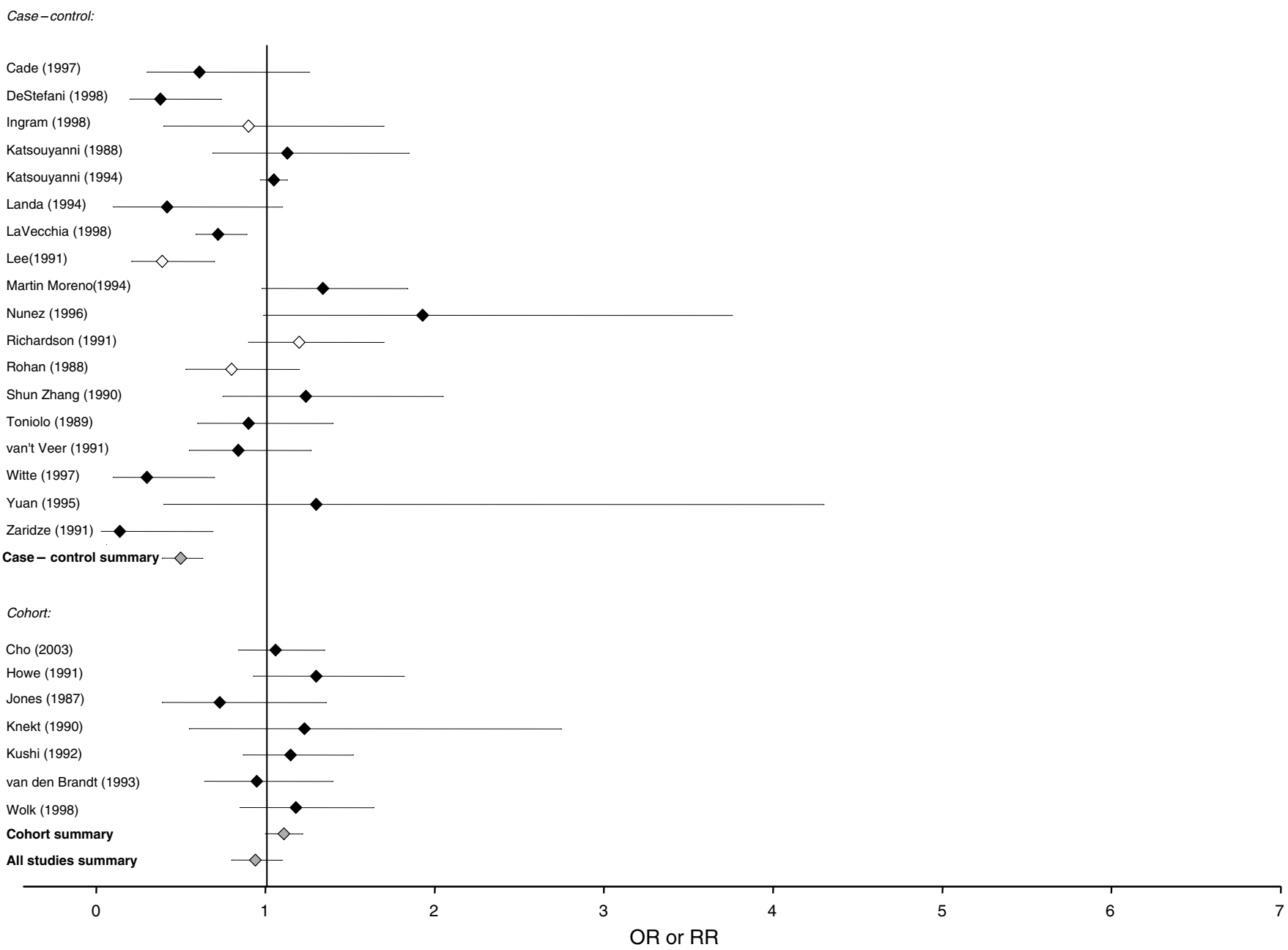

Figure I (Continued)

milk and cheese. The summary relative risks for meat intake were 1.17 (95\% CI: $1.06-1.29)$ for all studies, 1.13 (95\% CI: $1.01-1.25)$ for case-control studies alone and 1.32 (95\% CI: $1.12-1.56)$ for cohort studies alone. The summary relative risks for milk were 1.12 (95\% CI: $0.88-1.43)$ for all studies, $1.25(0.99-1.58)$ for casecontrol studies alone and 0.76 (95\% CI: $0.42-1.40)$ for cohort studies alone, and the summary relative risks for cheese were 1.26 (95\% CI: $0.96-1.66)$ for all studies and 1.30 (95\% CI: 0.89-1.92) for case-control studies alone.

\section{Analysis of sources of variation for studies of total fat and breast cancer risk}

As has already been noted, the studies included in the analysis differed in a number of aspects of their design and execution, and were reported from countries that are known to have wide differences in breast cancer risk. We examine below the influence of some of these sources of heterogeneity on the results presented in the previous sections. Owing to the small number of studies available after division into subgroups, we have confined our attention to those studies that reported the results of nutrient analysis for total fat intake and breast cancer risk.

The principal sources of variation in the study methodology examined were the extent to which studies met the methodological standards described above, the sources from which control or comparison groups were selected, the partitioning of nutrient intake and the geographic region where the studies were carried out.

Methodological standards The summary relative risks were calculated for studies classified according to the proportion of methodological standards met (see Methods section). The summary relative risk for the relationship of total fat intake to breast cancer risk, for all 26 studies that met $80 \%$ or more of the standards, was 1.17 (95\% CI: $1.03-1.32)$. For the 11 studies that met between 70 and $80 \%$ of standards, the summary relative risk was 1.08 (95\% CI: $0.93-1.24$ ), and for the nine studies that met $70 \%$ or less of the standards the relative risk was 0.91 (95\% CI: $0.59-1.40)$.

Source of controls The summary relative risk for total fat and breast cancer risk was 1.14 (95\% CI: $1.04-1.25$ ) for the 25 studies in Figure 1 that selected control or comparison groups from defined nonhospital populations. The 11 case-control studies in this group had a summary relative risk of 1.12 (95\% CI: $0.96-1.31$ ). The 14 case-control studies that selected controls from hospital populations had a summary relative risk of 1.11 (95\% CI: $0.84-$ 1.47). 
A

Case-control:

Meat

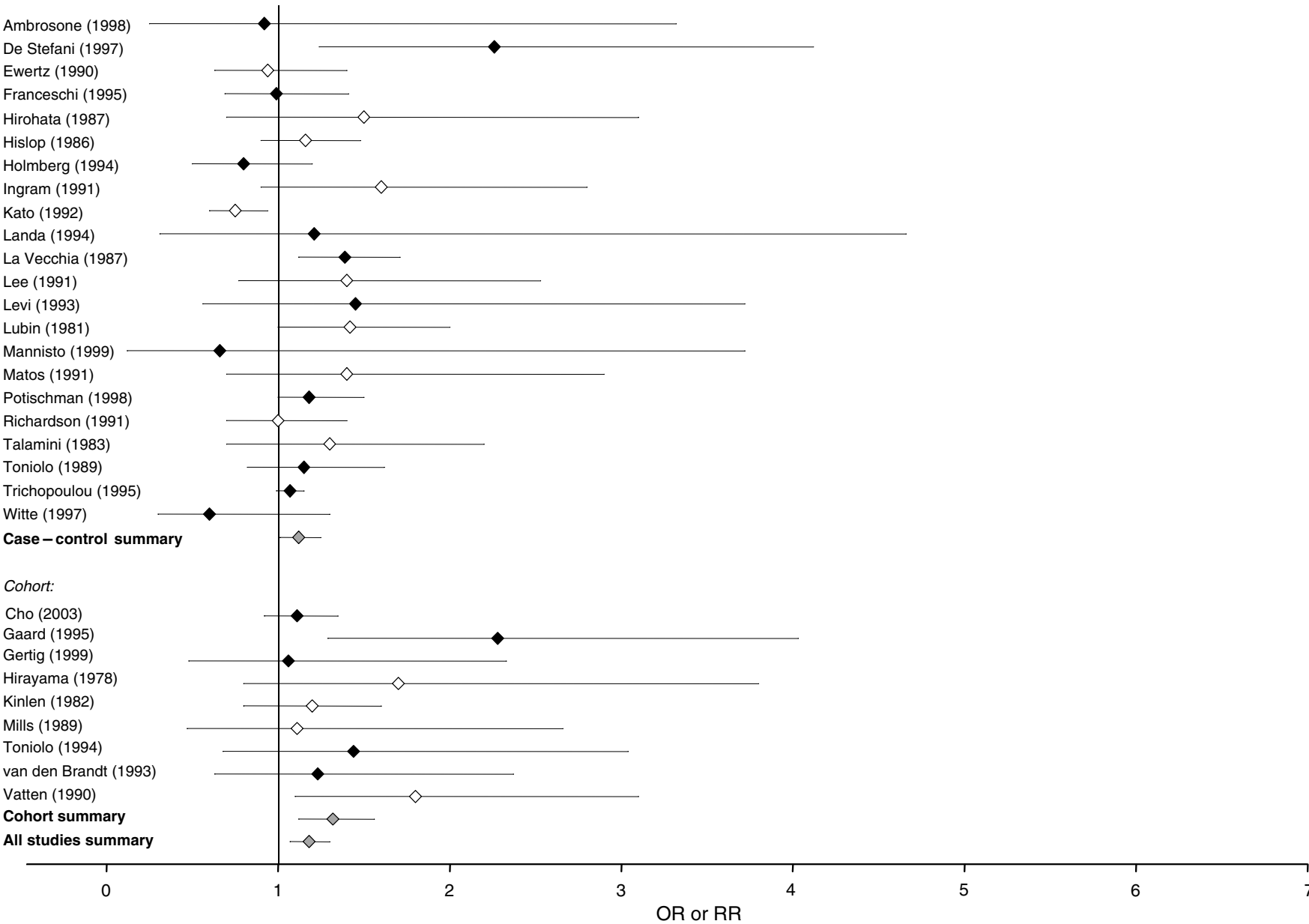

Figure 2 Relative risks for $(\mathbf{A})$ meat $(\mathbf{B})$ milk and $(\mathbf{C})$ cheese intake and breast cancer risk. Cls are $95 \%$. Closed diamond= relative risk adjusted for energy intake. Open diamond = relative risk unadjusted for energy intake. Grey diamond = summary relative risk results of the meta-analysis.

Partitioning of nutrient intake The summary relative risk for studies that partitioned nutrient intake into quintiles was 1.07 (95\% CI: $0.94-1.21$ ) for all studies and 1.01 (95\% CI: $0.83-1.24)$ for case-control studies; for studies that used quartiles, $1.12(95 \%$ CI: $0.95-1.32)$ for all studies and 1.16 (95\% CI: $0.91-1.48)$ for case - control studies; and for studies that used tertiles, $1.15(95 \%$ CI: $0.66-1.99)$ for all studies and 1.07 (95\% CI: 0.56-2.05) for case-control studies.

Geographic variation To examine the possible influence of the country in which they were carried out, studies were divided into four geographical categories. The summary relative risk for European studies $(n=22)$ was 1.17 (95\% CI: $1.02-1.34)$; for North American studies $(n=15) 1.04$ (95\% CI: 0.91-1.18) and for Asia $(n=6) 1.42$ (95\% CI: $0.87-2.30)$.

Regression analysis To examine the independent contribution of the factors considered above, regression analysis was carried out, in which the log of the relative risk for total fat intake in each study, weighted by the reciprocal of its variance, was the dependent variable and study quality score, geographical area, study design and type of controls were the independent variables. However, univariate analysis showed none of these variables to be significantly associated with the response; but, the type of controls and geographic location were significantly associated with the logrelative risk when they were both in the model. Studies using population-based controls had higher relative risks than those using hospital-based controls $(P=0.002)$, and both European and Asian studies had higher relative risks than North American studies $(P=0.006$ and 0.05 , respectively). Interactions between all four variables were examined and no significant interactions were found.

\section{DISCUSSION}

This quantitative summary of the published literature on the risk of breast cancer associated with dietary fat intake suggests that a higher intake of fat is associated with an increased risk of breast cancer. The summary relative risk for all studies that examined nutrient intake is calculated from the results of cohort and case-control studies, and in contrast to our previous publication, the results from these different designs for epidemiological investigation gave very similar results. This conclusion is based on 45 studies that contain a total of 25015 cases of breast cancer and 580000 control or comparison subjects. The summary risk estimates from all case-control and cohort studies were very similar, although neither was 


\section{B}

Case-control:

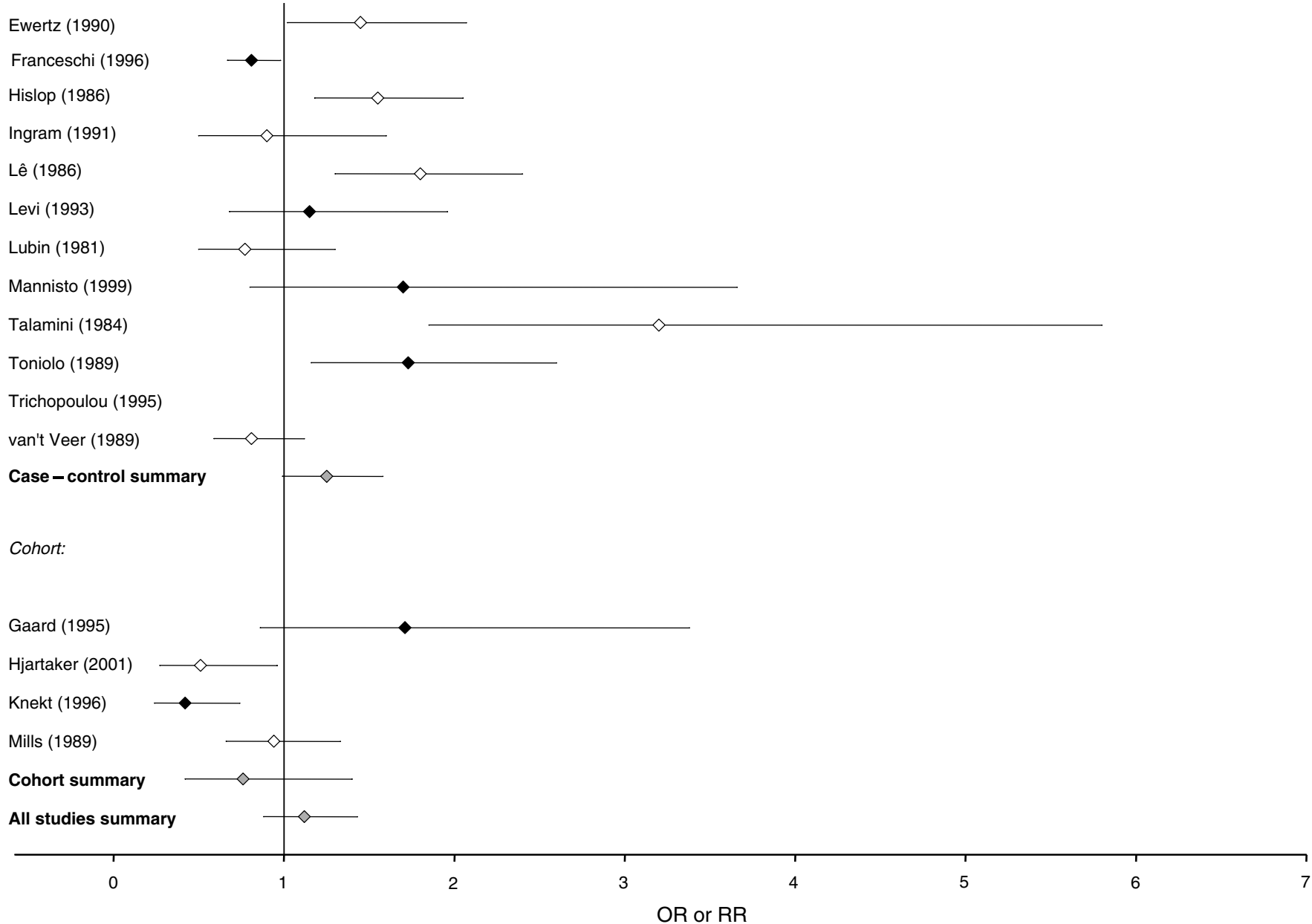

Figure 2 (Continued)

statistically significant. The combined estimate, however, was statistically significant as was the summary risk estimate for cohort studies that met $80 \%$ or more of the quality standards.

Other differences between our earlier analysis and the present findings are summarised in Table 3. (The software used for our earlier analysis contained a programming error, which had a small influence on the results, but did not affect the conclusions of the paper. The table shows the corrected values of the published results.) Compared to the 1993 analysis, which was based on 23 studies, the present analysis based on 45 studies, gave smaller odds ratios for case-control studies, and slightly larger relatives risks for cohort studies. Neither study design gave significant estimates of risk in the previous or present analysis, but the combined estimates were significant in both. Among studies of higher quality, the estimate from cohort studies was significant in the present results, while the estimate from case-control studies was no longer significant. Strong evidence of substantial variation in results according to the geographical location of the study was present in both analyses. Point estimates of risk associated with fat intake were highest in Asia, lowest in North America and intermediate in Europe, findings that may be related to differences in the underlying variation in dietary fat intake in the populations in these regions.
Different studies partitioned fat intake in different ways, but an examination of the results obtained suggested that partitioning by tertiles, quartiles or quintiles gave very similar estimates. Among the major subtypes of fat, we found that saturated fat was significantly associated with breast cancer risk in both casecontrol and cohort studies, and that results were significant in the present but not the previous analysis. Mono- and polyunsaturated fat were not significantly associated with breast cancer in either case-control or cohort studies, or in summaries of all studies in the present analysis.

Our conclusion about the relationship of dietary fat to risk of breast cancer is supported to some degree by studies of specific foods. Of the studies that examined intake of foods in relation to risk of breast cancer, the largest number had examined meat consumption, which was significantly associated with breast cancer risk in this meta-analysis, in the overall estimate of risk and in both case-control and cohort studies considered separately. Fewer studies examined milk and cheese intake in relation to breast cancer risk, and although point estimates for the summary relative risks of all studies were greater than unity for both foods, neither was statistically significant.

Although this meta-analysis was based on published results, we were able to generate results similar to those of a previously published combined analysis of a subset of the cohort studies examined here. The differences between the results obtained in 


\section{C}

Case-control:

Cheese

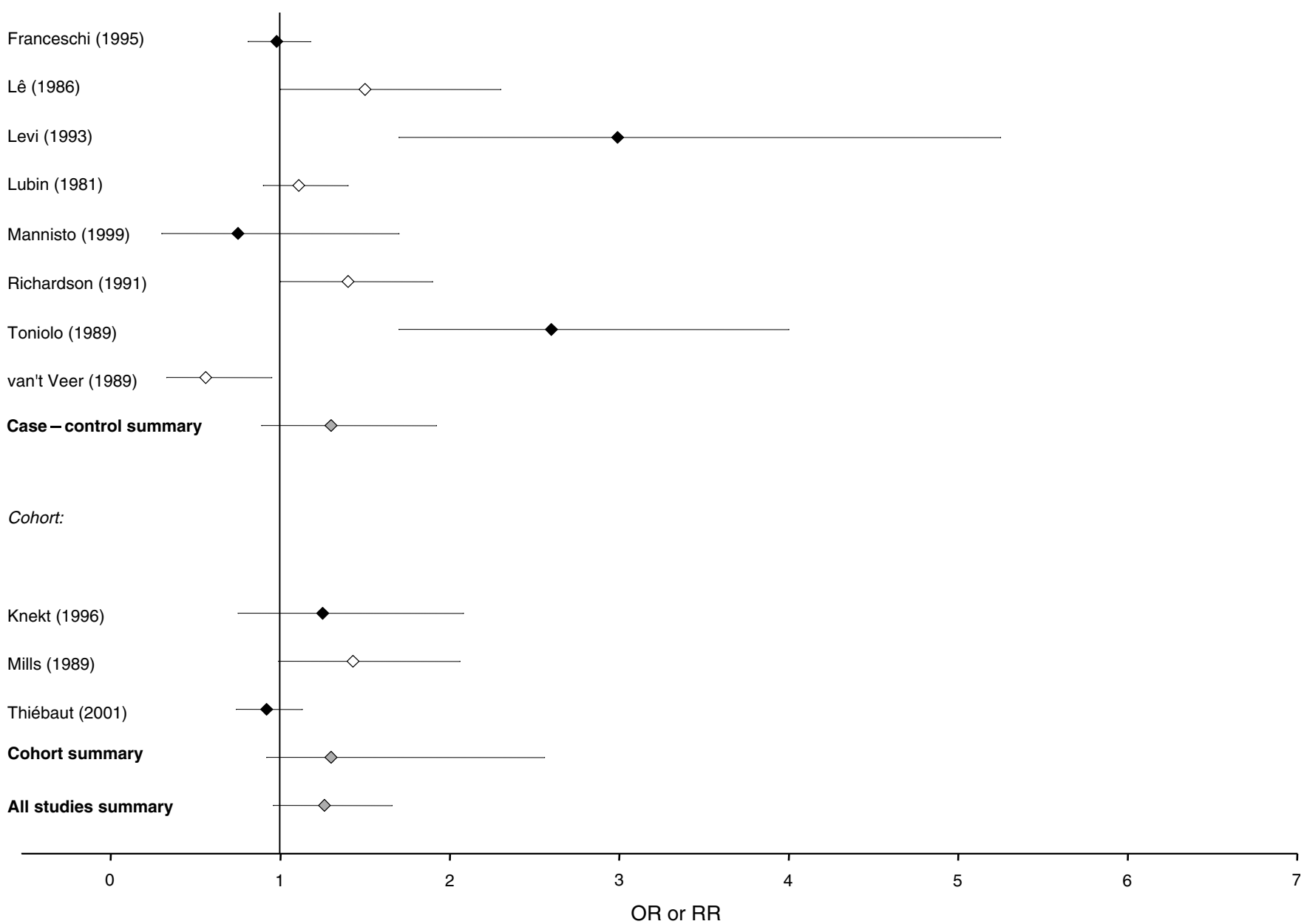

Figure 2 (Continued)

case-control and cohort studies might be attributable to recall bias, but as similar results were found here in the two research designs it is not likely that this potential source of bias has a major influence.

The biological plausibility of an association between dietary fat and breast cancer risk is shown by the effect that dietary fat intake has on mammary carcinogenesis in animals (see, for reviews, Freedman et al, 1990; Welsch, 1994), which appears to be distinct from the effect of calories, as well as by the known biological effects of fat. Potential mechanisms include the generation from fatty acids of eicosanoids, the generation of free radicals and mutagenic compounds such as malondialdehyde by lipid peroxidation and the modulation of genes that are involved in mammary carcinogenesis (Cohen et al, 1986).

Despite the strong evidence that breast cancer is influenced by environmental factors, and the consistency of the ecological analyses suggesting that dietary fat is one of these factors, epidemiological investigations of the relationship of dietary fat to breast cancer incidence based upon the measurement of dietary intakes in individuals with case-control and cohort studies, have given much less consistent results. However, in considering these results, and those given above in our quantitative summary of the published literature, we need to consider the effects of the relative homogeneity of fat intake within populations and error in the measurement of fat intake, both factors that are expected to attenuate any true association between dietary fat and breast cancer.

For example, homogeneity is shown by the range across quintiles of total fat intake in the Nurses Health Study (Willett et al, 1987), a large cohort study in North America, which was only $32-44 \%$ of calories, compared to the international range of $15 \%$ or less to more than $40 \%$ of calories. This narrow range of fat intake is expected, from international data, to be associated with a relative risk of only 1.4 in the highest quintile of fat intake relative to the lowest. When the measurement error known to be associated with the food frequency questionnaire used is taken into account, this estimate of the relative risk is reduced to 1.16, a figure that is close to the summary relative risk of our meta-analysis (Prentice et al, 1988).

Measurement error in the food frequency questionnaires used in most studies may lead to overestimation of the range of intakes and may also lead to attenuation of risk (Prentice, 2003). The cohort study of Bingham et al (2003) showed a small and nonsignificant increase in the risk of breast cancer when fat intake was estimated from a food frequency questionnaire, but a larger and significant increase when estimated from food records obtained from the same subjects.

Experimental trials, in which the range of fat intake is increased beyond that seen in most Western populations, are a means of overcoming the limitations of observational epidemiology that 
Table 3 Summary risks for 1993 and present meta-analyses

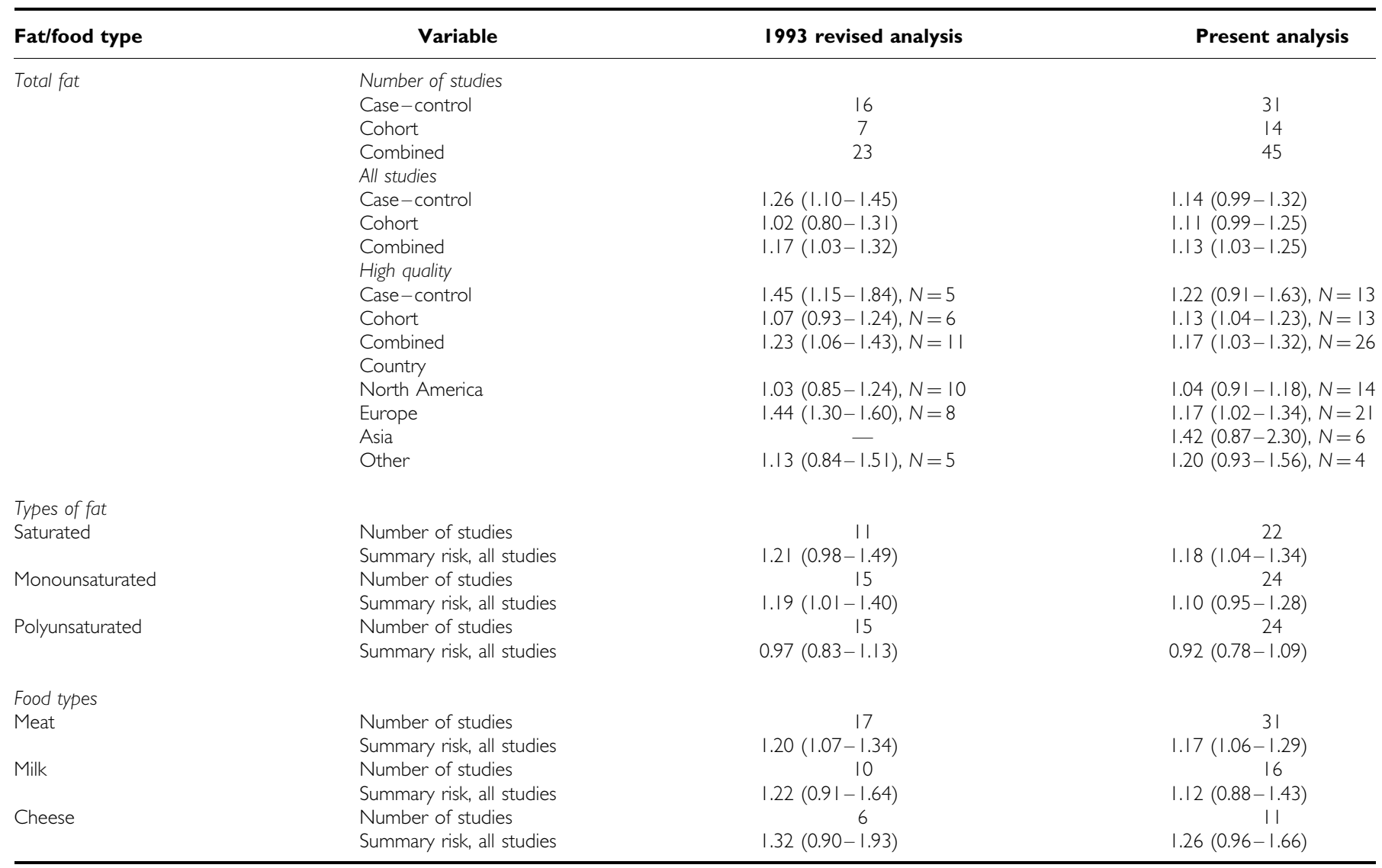

arise from homogeneity of intake and measurement error, and provide the strongest evidence available concerning a causal relationship of dietary fat intake to breast cancer risk. Further, such trials are the only means available to determine whether breast cancer risk in high-risk subjects can be reduced by changing dietary fat intake.

\section{REFERENCES}

Ambrosone CB, Freudenheim JL, Sinha R, Graham S, Marshall JR, Vena JE, Laughlin R, Nemoto T, Shields PG (1998) Breast cancer risk, meat consumption and $\mathrm{N}$-acetyltransferase (NAT2) genetic polymorphisms. Int J Cancer 75(6): 825-830

Bingham SA, Luben R, Welch A, Wareham N, Khaw K-T, Day N (2003) Are imprecise methods obscuring a relation between fat and breast cancer? Lancet 362: 212-214

Boyd NF, Martin LJ, Noffel M, Lockwood GA, Tritchler DL (1993) A metaanalysis of studies of dietary fat and breast cancer risk. Br J Cancer 68: $627-636$

Cohen LA, Choi K, Weisburger JH, Rose DP (1986) Effect of varying proportions of dietary fat on the development of $\mathrm{N}$-nitrosomethylurea-induced rat mammary tumors. Anticancer Res 6: $215-218$

De stefani E, Correa P, Ronco A, Mendilaharsu M, Guidobono M, Deneopellegrini H (1997) Dietary fiber and risk of breast cancer: a casecontrol study in Uruguay. Nutr Cancer 28: 14-19

De stefani E, Deneo-pellegrini H, Mendilaharsu M, Ronco A (1998) Essential fatty acids and breast cancer: a case - control study in Uruguay. Int J Cancer 76: 491 - 494

DerSimonian R, Laird N (1986) Meta-analysis in clinical trials. Control Clin Trials 7: $177-188$

\section{ACKNOWLEDGEMENTS}

Ms KN Vogt was supported by an award from the Department of Medical Biophysics of the University of Toronto. Ms BS Connolly was supported by an award from the Institute of Medical Sciences of the University of Toronto.

Ewertz M, Gill C (1990) Dietary factors and breast-cancer risk in Denmark. Int J Cancer 46: 779-784

Fay MP, Freedman LS, Clifford CK, Midthune DN (1997) Effect of different types and amounts of fat on the development of mammary tumors in rodents: a review. Cancer Res 57: 3979-3988

Fleiss JL (1981) Statistical Methods for Rates and Proportions. New York: John Wiley \& Sons

Franceschi S, Favero A, Decarli A, Negri E, La Vecchia C, Ferraroni M, Russo A, Salvini S, Amadori D, Conti E, Montella M, Giacosa A (1996) Intake of macronutrients and risk of breast cancer. Lancet 347: 1351 1356

Franceschi S, Favero A, La Vecchia C, Negri E, Dal Maso L, Salvini S, Decarli A, Giacosa A (1995) Influence of food groups and food diversity on breast cancer risk in Italy. Int J Cancer 63: 785-789

Freedman LS, Clifford C, Messina M (1990) Analysis of dietary fat, calories, body weight and the development of mammary tumours in rats and mice: a review. Cancer Res 50: 5710-5719

Gaard M, Tretli S, Loken EB (1995) Dietary fat and the risk of breast cancer: a prospective study of 25892 Norwegian women. Int J Cancer 63: 13-17 Gertig DM, Hankinson SE, Hough H, Spiegelman D, Colditz GA, Willett WC, Kelsey KT, Hunter DJ (1999) $N$-acetyl transferase 2 genotypes, meat intake and breast cancer risk. Int J Cancer 80: 13-17 
Graham S, Hellmann R, Marshall J, Freudenheim J, Vena J, Swanson M, Zielezny M, Nemoto T, Stubbe N, Raimondo T (1991) Nutritional epidemiology of postmenopausal breast cancer in western New York. Am J Epidemiol 134: 552 - 566

Graham S, Marshall J, Mettlin C, Rzepka T, Nemoto T, Byers T (1982) Diet in the epidemiology of breast cancer. Am J Epidemiol 116: 68-75

Graham S, Zielezny M, Marshall J, Priore J, Freudenheim J, Brasure J, Haughey B, Nasca P, Zdeb M (1992) Diet in the epidemiology of postmenopausal breast cancer in the New York State cohort. Am J Epidemiol 136: $1327-1337$

Hirayama T (1978) Epidemiology of breast cancer with special reference to the role of diet. Prev Med 7: 173-195

Hirohata T, Nomura AM, Hankin JH, Kolonel LN, Lee J (1987) An epidemiologic study on the association between diet and breast cancer. $J$ Natl Cancer Inst 78: 595-600

Hirohata T, Shigematsu T, Nomura AMY, Nomura Y, Horie A, Hirohata I (1985) Occurrence of breast cancer in relation to diet and reproductive history: a case-control study in Fukuoka, Japan. Natl Cancer Inst Monogr 69: $187-190$

Hislop TG, Coldman AJ, Elwood JM, Brauer G, Kan L (1986) Childhood and recent eating patterns and risk of breast cancer. Cancer Detect Prev 9: $47-58$

Hjartaker A, Laake P, Lund E (2001) Childhood and adult milk consumption and risk of premenopausal breast cancer in a cohort of 48844 women - the Norwegian women and cancer study. Int J Cancer 93: $888-893$

Holmberg L, Ohlander EM, Byers T, Zack M, Wolk A, Bergstrom R, Bergkvist L, Thurfjell E, Bruce A, Adami HO (1994) Diet and breast cancer risk. Results from a population-based, case-control study in Sweden. Arch Intern Med 154: 1805-1811

Holmes MD, Hunter DJ, Colditz GA, Stampfer MJ, Hankinson SE, Speizer FE, Rosner B, Willett WC (1999) Association of dietary fat intake and fatty acids with risk of breast cancer. JAMA 281: 914-920

Howe G, Rohan T, Decarli A, Iscovich J, Kaldor J, Katsouyanni K, Marubini E, Miller A, Riboli E, Toniolo P, Trichopoulos D (1991a) The association between alcohol and breast cancer risk: evidence from the combined analysis of six dietary case - control studies. Int J Cancer 47: 707-710

Howe GR, Friedenreich CM, Jain M, Miller AB (1991b) A cohort study of fat intake and risk of breast cancer. J Natl Cancer Inst 83: 336-340

Hunter DJ, Spiegelman D, Adami HO, Beeson L, van den Brandt PA, Folsom AR, Fraser GE, Goldbohm A, Graham S, Howe GR, Kushi LH, Marshall JR, McDermott A, Miller AB, Speizer FE, Wolk A, Yaun SS, Willett W (1996) Cohort studies of fat intake and the risk of breast cancer - a pooled analysis. $N$ Engl J Med 334: 356-361

Ingram DM, Nottage E, Roberts T (1991) The role of diet in the development of breast cancer: a case-control study of patients with breast cancer, benign epithelial hyperplasia and fibrocystic disease of the breast. Br J Cancer 64: $187-191$

Jones DY, Schatzkin A, Green SB, Block G, Brinton LA, Ziegler GG, Hoover R, Taylor PR (1987) Dietary fat and breast cancer in the National Health and Nutrition Examination Survey I Epidemiologic Follow-up Study. Natl Cancer Inst 79: 465-471

Kato I, Miura S, Kasumi F, Iwase T, Tashiro H, Fujita Y, Koyama H, Ikeda T, Fujiwara K, Saotome K, Asaishi K, Abe R, Nihei M, Ishida T, Yokow T, Yamamoto H, Murata M (1992) A case-control study of breast cancer among Japanese women: with special reference to family history and reproductive and dietary factors. Breast Cancer Res Treat 24: 51-59

Katsouyanni K, Trichopoulos D, Boyle P, Xirouchaki E, Trichopoulou A, Lisseos B, Vasilaros S, MacMahon B (1986) Diet and breast cancer: a case - control study in Greece. Int J Cancer 38: 815-820

Katsouyanni K, Trichopoulou A, Stuver S, Garas Y, Kritselis A, Kyriakou G, Stoikidou M, Boyle P, Trichopoulos D (1994) The association on fat and other macronutrients with breast cancer: a case-control study from Greece. Br J Cancer 70: 537-541

Katsouyanni K, Willett W, Trichopoulos D, Boyle P, Trichopoulou A, Vasilaros S, Papadiamantis J, MacMahon B (1988) Risk of breast cancer among Greek women in relation to nutrient intake. Cancer 61: $181-185$

Kinlen LJ (1982) Meat and fat consumption and cancer mortality: a study of strict religious orders in Britain. Lancet 1: 946-949

Knekt P, Albanes D, Seppanen R, Aromaa A, Jarvinen R, Hyvonen L, Teppo L, Pukkala E (1990) Dietary fat and risk of breast cancer. Am J Clin Nutr 52: $903-908$

Knekt P, Jarvinen R, Seppanen R, Pukkala E, Aromaa A (1996) Intake of dairy products and the risk of breast cancer 7. Br J Cancer 73: 687-691
Kushi LH, Sellers TA, Potter JD, Nelson CL, Munger RG, Kaye SA, Folsom AR (1992) Dietary fat and postmenopausal breast cancer. J Natl Cancer Inst 84: $1092-1099$

Lacey Jr JV, Devesa SS, Brinton LA (2002) Recent trends in breast cancer incidence and mortality. Environ Mol Mutagen 39: 82-88

Landa MC, Frago N, Tres A (1994) Diet and the risk of breast cancer in Spain. Eur J Cancer Prev 3: 313-320

La Vecchia C, Decarli A, Franceschi S, Gentile A, Negri E, Parazzini F (1987) Dietary factors and the risk of breast cancer. Nutr Cancer 10: 205-214

Le MG, Moulton LH, Hill C, Kramar A (1986) Consumption of dairy produce and alcohol in a case-control study of breast cancer. $J$ Natl Cancer Inst 77: 633-636

Lee HP, Gourley L, Duffy SW, Esteve J, Lee J, Day NE (1991) Dietary effects on breast-cancer risk in Singapore. Lancet 337: 1197-1200

Levi F, La Vecchia C, Gulie C, Negri E (1993) Dietary factors and breast cancer risk in Vaud, Switzerland 12. Nutr Cancer 19: 327-335

Lubin JH, Burns PE, Blot WJ, Ziegler RG, Lees AW, Fraumeni JFJ (1981) Dietary factors and breast cancer risk. Int J Cancer 28: 685-689

Lubin J, Wax Y, Modan B (1986) Role of fat, animal protein, and dietary fiber in breast cancer etiology: a case-control study. J Natl Cancer Inst 77: $605-612$

Mannisto S, Pietinen P, Virtanen M, Kataja V, Uusitupa M (1999) Diet and the risk of breast cancer in a case-control study: does the threat of disease have an influence on recall bias? J Clin Epidemiol 52: 429-439

Martin-Moreno JM, Willett WC, Gorgojo L, Banegas JR, Rodriguez-Artalejo F, Fernandez-Rodriguez JC, Maisonneuve P, Boyle P (1994) Dietary fat, olive oil intake and breast cancer risk. Int J Cancer 58: 774-780

Matos EL, Thomas DB, Sobel N, Vuota D (1991) Breast cancer in Argentina: case-control study with special reference to meat eating habits. Neoplasma 38: 357-366

Miller AB, Kelly A, Choi NW, Matthews V, Morgan RW, Munan L, Burch JD, Feather J, Howe GR, Jain M (1978) A study of diet and breast cancer. Am J Epidemiol 107: 499-509

Mills PK, Beeson WL, Phillips RL, Fraser GE (1989) Dietary habits and breast cancer incidence among Seventh-day Adventists. Cancer 64: 582 590

Nunez C, Carbajal A, Belmonte S, Moreiras O, Varela G (1996) A case control study of the relationship between diet and breast cancer in a sample from 3 Spanish hospital populations. Effects of food, energy and nutrient intake). Rev Clin Esp 196: $75-81$

Pike MC, Kolonel LN, Henderson BE, Wilkens LR, Hankin JH, Feigelson HS, Wan PC, Stram DO, Nomura AM (2002) Breast cancer in a multiethnic cohort in Hawaii and Los Angeles: risk factor-adjusted incidence in Japanese equals and in Hawaiians exceeds that in Whites. Cancer Epidemiol Biomarkers Prev 11: 795-800

Potischman N, Weiss HA, Swanson CA, Coates RJ, Gammon MD, Malone KE, Brogan D, Stanford JL, Hoover RN, Brinton LA (1998) Diet during adolescence and risk of breast cancer among young women. J Natl Cancer Inst 90: 226-233

Prentice RL (2003) Dietary assessment and the reliability of nutritional epidemiology reports. Lancet 362: $182-183$

Prentice RL, Kakar F, Hursting S, Sheppard L, Klein R, Kushi LH (1988) Aspects of the rationale for the women's health trial. J Natl Cancer Inst 80: $802-814$

Prentice RL, Sheppard L (1990) Dietary fat and cancer: consistency of the epidemiologic data, and disease prevention that may follow from a practical reduction in fat consumption. Cancer Causes Control 1: 81-97

Pryor M, Slattery ML, Robison LM, Egger M (1989) Adolescent diet and breast cancer in Utah. Cancer Res 49: 2161-2167

Richardson S, Gerber M, Cenee S (1991) The role of fat, animal protein and some vitamin consumption in breast cancer: a case-control study in southern France. Int J Cancer 48: 1-9

Rohan TE, McMichael AJ, Baghurst PA (1988) A population-based casecontrol study of diet and breast cancer in Australia. Am J Epidemiol 128: $478-489$

Shun-Zhang Y, Rui-Fang L, Da-Dao X, Howe GR (1990) A case-control study of dietary and nondietary risk factors for breast cancer in Shanghai. Cancer Res 50: 5017-5021

Talamini R, La Vecchia C, Decarli A, Franceschi S, Grattoni E, Grigoletto E, Liberati A, Tognoni G (1984) Social factors, diet and breast cancer in a northern Italian population. Br J Cancer 49: 723-729

Thiebaut AC, Clavel-Chapelon F (2001) Fat consumption and breast cancer: preliminary results from the E3N - epic cohort). Bull Cancer 88: 954 958 
Toniolo P, Riboli E, Protta F, Charrel M, Cappa APM (1989) Calorieproviding nutrients and risk of breast cancer. J Natl Cancer Inst 81: 278 286

Toniolo P, Riboli E, Shore RE, Pasternack BS (1994) Consumption of meat, animal products, protein, and fat and risk of breast cancer: a prospective cohort study in New York. Epidemiology 5: $391-397$

Trichopoulou A, Katsouyanni K, Stuver S, Tzala L, Gnardellis C, Rimm E, Trichopouls D (1995) Consumption of olive oil and specific food groups in relation to breast cancer risk in Greece. J Natl Cancer Inst 87: $110-116$

van den Brandt PA, Van't Veer P, Goldbohm RA, Dorant E, Volovics A, Hermus RJ, Sturmans F (1993) A prospective cohort study on dietary fat and the risk of postmenopausal breast cancer. Cancer Res 53: $75-82$

Van't Veer P, Dekker JM, Lamers JWJ, Kok FJ, Schouten EG, Brants HAM, Sturmans F, Hermus RJJ (1989) Consumption of fermented milk products and breast cancer: A case-control study in the Netherlands. Cancer Res 49: 4020-4023

Van't Veer P, Van Leer EM, Rietdijk A, Kok FJ, Schouten EG, Hermus RJ, Sturmans F (1991) Combination of dietary factors in relation to breast cancer occurrence. Int J Cancer 47: 649-653

Vatten LJ, Solvoll K, Loken EB (1990) Frequency of meat and fish intake and risk of breast cancer in a prospective study of 14500 Norwegian women. Int J Cancer 46: 12 - 15

Velie E, Kulldorff M, Schairer C, Block G, Albanes D, Schatzkin A (2000) Dietary fat, fat subtypes, and breast cancer in postmenopausal women: a prospective cohort study. J Natl Cancer Inst 92: 833-839

Wakai K, Dillon DS, Ohno Y, Prihartono J, Budiningsih S, Ramli M, Darwis I, Tjindarbumi D, Tjahjadi G, Soetrisno E, Roostini ES, Sakamoto G, Herman S, Cornain S (2000) Fat intake and breast cancer risk in an area where fat intake is low: a case-control study in Indonesia. Int $J$ Epidemiol 29: $20-28$
Wang Q, Li L, Zhu W, Et A (2000) Study on risk factors of breast cancer among urban women in China). Zhonghua Liu Xing Bing Xue Za Zhi 21: $216-220$

Welsch CW (1994) Interrelationship between dietary lipids and calories and experimental mammary gland tumorigenesis. Cancer 74: 1055-1062

Willett WC, Hunter DJ, Stampfer MJ, Colditz G, Manson JE, Spiegelman D, Rosner B, Hennekens CH, Speizer FE (1992) Dietary fat and fiber in relation to risk of breast cancer. an 8-year follow-up. JAMA 268: 2037 2044

Willett WC, Stampfer MJ, Colditz GA, Rosner BA, Hennekens CH, Speizer FE (1987) Dietary fat and the risk of breast cancer. N Engl J Med 316: 22 -

Witte JS, Ursin G, Siemiatycki J, Thompson WD, Paganini-Hill A, Haile RW (1997) Diet and premenopausal bilateral breast cancer: a case-control study. Breast Cancer Res Treat 42: 243-251

Wolk A, Bergstrom R, Hunter DJ, Willett W, Ljung H, Holmberg L, Bergkvist L, Bruce A, Adami H-O (1998) A prospective study of association of monounsaturated fat and other types of fat with risk of breast cancer. Arch Intern Med 158: 41 - 45

Wu AH, Ziegler RG, Pike MC, Nomura AMY, West DW, Kolonel LN, HornRoss PL, Rosenthal JF, Hoover RN (1996) Menstrual and reproductive factors and risk of breast cancer in Asian-Americans. $\mathrm{Br} J$ Cancer 73: $680-686$

Yuan JM, Wang QS, Ross RK, Henderson BE, Yu MC (1995) Diet and breast cancer in Shanghai and Tianjin, China. Br J Cancer 71: 1353-1358

Zaridze D, Lifanova Y, Maximovitch D, Day NE, Duffy SW (1991) Diet, alcohol consumption and reproductive factors in a case-control study of breast cancer in Moscow. Int J Cancer 48: 493-501

Ziegler RG, Hoover RN, Pike MC, Hildesheim A, Nomura AMY, West DW, Wu-williams AH, Kolonel LN, Horn-Ross PL, Rosenthal JF, Hyer MB (1993) Migration patterns and breast cancer risk in Asian-American women. J Natl Cancer Inst 85: 1819 - 1827 